\title{
Combined system of energy generation from biomass and solar energy
}

\author{
Renata Włodarczyk ${ }^{1, *}$, Robert Zarzycki ${ }^{1}$ and Zbigniew Bis $^{1}$ \\ ${ }^{1}$ Energy Engineering Department, Faculty of Infrastructure and Environment, Czestochowa \\ University of Technology, Brzeznicka Street 60A, 42-200 Czestochowa, Poland
}

\begin{abstract}
The study discussed the design and principle of operation of an intelligent system that uses renewable energy sources (RES) in the form of biomass and solar energy. The aim of the system is to supply heat to public utility buildings in Częstochowa, Poland. The system of renewable energy conversion includes boilers fuelled by biomass in the form of pellets and evacuated tube solar collectors. An additional equipment for the system is buffer tanks, computer-aided monitoring of operating parameters of the system and calorimeters with the system of automation and control of the system operation. The study discusses possible problems with the use of solar installations and processes of degradation of metal components, glass tubes and working medium. The basic criteria that have to be met by the working fluid in the system, parameters that have to be periodically controlled during the use of solar installations and mixtures of fluids available in the renewable energy market were presented.
\end{abstract}

\section{Introduction}

Systems of preparation of domestic hot water are constantly developed to ensure comfort with low energy consumption. Low temperature installations have been designed using innovative heating equipment as energy sources for these installations. Limitation of energy consumption has become possible through improved efficiency of processes and equipment used during preparation of domestic hot water. As one of the innovative installations based on renewable sources, solar collectors are becoming more and more popular. They have been used in heating systems, especially for preparation of domestic hot water. One of advanced solutions is a systematic installation that uses solar energy and biomass energy. Both sources of energy are renewable, whereas unlike fossil fuels, biomass shows a zero carbon dioxide balance i.e. combustion of biomass generates the same amount of carbon dioxide as plants in the growth period.

This study presents a solution that allows for the combination of renewable energy sources: biomass and solar energy. The system of energy conversion includes boilers fuelled by biomass and evacuated tube solar collectors. The study presents the functional problems and possible phenomena of degradation that occur in solar installations with the example of the combined system.

\footnotetext{
*Corresponding author: rwlodarczyk@is.pcz.czest.pl
} 


\section{Parameters of the system for generation of energy from biomass and solar illumination}

The combined system of energy generation from biomass and the sun is composed of the heating plant fuelled by pellet from biomass and installation of evacuated tube solar collectors [1]. Fig. 1 presents a design of the building with boilers, solar collectors and necessary fittings and control systems used for correct system operation. The system presented allows for the supply of domestic hot water and heat to the buildings of the Faculty of Infrastructure and Environment with a total floor area of ca. 5,300 $\mathrm{m}^{2}$.



b)

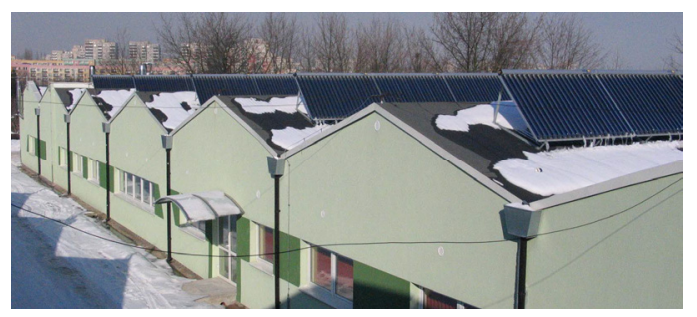

Fig. 1. Building equipped in the system for generation of energy from biomass and solar illumination: a) diagram of the system, b) top view of the building.

The design of the system of energy generation from biomass and solar energy is presented in Fig. 2. It is composed of a set of solar collectors with total area of $63 \mathrm{~m}^{2}$, two boilers fuelled by biomass (pellet), buffer tanks that allow for heat storage, heat exchangers, calorimeters, fittings and automation systems. The system of energy conversion from biomass is composed of a pellet storage room (Figs. 1, 3a) that fuel stock to be collected for the period of ca. 1 month. There are channels in the roof of the pellet storage room (Fig. 3a) that allow for an automated filling of the storage area from the tankers that transport the fuel. This solution substantially accelerates and facilitates the process of filling the storage room with pellet. 


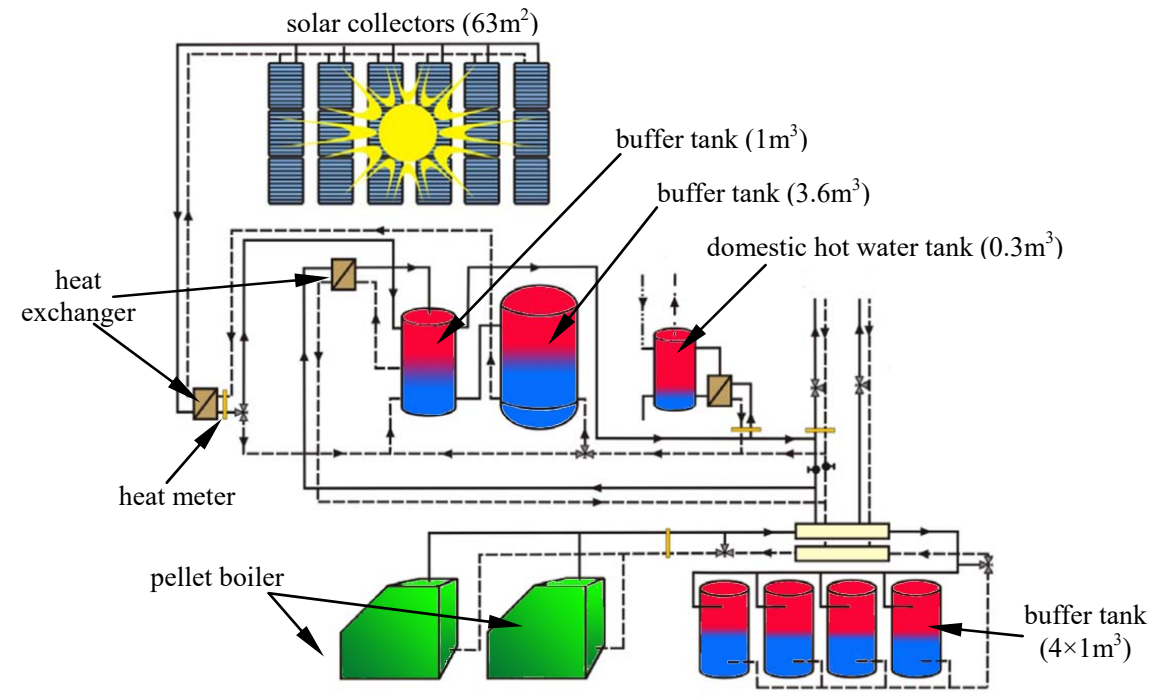

Fig. 2. Diagram of connections of the system for generation of energy from biomass and solar illumination.

There are two augers aimed to transport pellet to boilers (Fig. 3b). If a high layer of pellet is present on the floor, the augers are gravitationally filled by the above fuel layer. When the fuel level in the storage room is insufficient, the pellet can pour into the auger chute, which may lead to stopping the supply of fuel to the boiler and its damping. In order to limit the risk of such events and allow for a complete emptying of the storage room, pellet sweeps made of elastic metal are moved over the floor surface (Fig. 3b). Their task is to constantly fill in the auger chute with pellet contained $n$ the storage room. This design of the fuel warehouse allows for a full automation and high safety of supplying pellet to boilers.

a)



b)



Fig. 3. Pellet warehouse: a) storage room floor with pellet sweep and b) auger conveyor.

Auger conveyors are used to transport fuel from storage rooms to two HDG Bavaria Compact C150 biomass boilers (Fig. 4). Nominal power of the boiler is $150 \mathrm{~kW}$. The boiler is equipped in a moving stepping grate with replaceable grate elements. Fuel is transported to the boiler by means of a dedicated auger (Fig. 4a). In order to limit the danger of fire, a back-burning protection with rotary feeder (Fig. 4a) is installed before the furnace, allowing for safe separation of fuel in the auger which supplies the fuel from the storage room to the boiler combustion chamber. There is a system installed over the back-burning 
protection to control the temperature of pellet supplied to the boiler and, in the case of a sudden increase in temperature (burning of pellet in the conveyor), to immediately put out the fire using a water extinguisher. The boiler is equipped in two ash sweep-off gears (Fig. 4c) and the automatic system for cleaning of the heat exchanger surfaces. In order to improve boiler efficiency and limit CO emissions to the atmosphere, a Lambda probe is installed behind the boiler (Fig. 4c) aimed to measure oxygen content in flue gas. The information obtained is transferred to the boiler control system (Fig. 4b) in order to supply the required air stream for burning so that optimal burning process conditions are ensured. Additional flue gas fans are installed at the boiler outlet (Figs. 4b, 4c) to ensure the required draft during burning in the case of low chimney installation. A peephole that allows for the control of the pellet combustion process is installed in the side wall of the combustion chamber (Fig. 4d).


Fig. 4. HDG Bavaria Compact $\mathrm{C} 150$ boilers that convert biomass in the form of pellets; a) side view; b) boiler view with installation of flue gas removal, c) boiler with ash tanks and flue gas extractor fan; d) peephole that allows for combustion process control.

The heat obtained in the combustion process is transported from boilers for heating the buildings of the Faculty of Infrastructure and Environment and can be stored in buffer tanks NEO-Cell B1000 with a total volume of $4 \mathrm{~m}^{3}$ (Fig. 5). Installation in the heating system of buffer tanks (Fig. 2) ensures maintaining a specific temperature of the medium in the heating installation.

The system of the use of solar energy is composed of evacuated tube solar collectors CPC 21 Star Azzurro Paradigma with a total active surface of $63 \mathrm{~m}^{2}$ (Fig. 1, Fig. 6a,b). Current designs available in the market include flat plate collectors and evacuated tube collectors. Both types are characterized by comparable performance in summer and higher performance of evacuated tube collectors in the winter period. Higher performance of evacuated tube collectors in the summer period results from its ability to absorb scattered radiation (due to presence of the coating that absorbs solar radiation on the tube surface) and 




Fig. 5. Buffer tanks NEO-Cell B1000.

limitation of heat loss due to vacuum in the glass tube of the collector. The fluid, characterized by adequate resistance to high temperatures (mostly glycol solution), circulates in copper tubes. Heated by the sun, medium starts to evaporate, which forces the convection transport of heat to the condenser tip. The condenser is used to transfer heat to the fluid and then, through the heat exchanger (Fig. 7a), to hot water tanks (Fig. 7b) with total volume of $4.6 \mathrm{~m}^{3}$, which are connected serially with the central heating installation (Fig. 2).


Fig. 6. Parabolic evacuated tube collectors: a) side view; b) method to fix the collector in the aluminium section.

a)
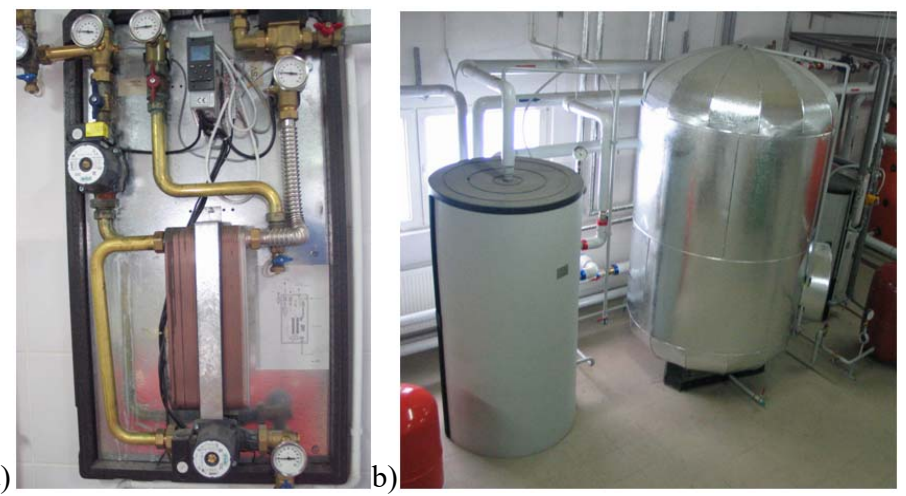

Fig. 7. a) Solar heat exchanger, b) hot water buffer tanks. 
Figure 8 presents weather data [2] during the heating season 2007/2008: maximum temperature $\left[{ }^{\circ} \mathrm{C}\right]$, minimum temperature $\left[{ }^{\circ} \mathrm{C}\right]$, sun hours $[\mathrm{h}]$, rainfall $[\mathrm{mm}]$, height of the snow cover $[\mathrm{cm}]$. Weather conditions have a significant impact on the heat demand for heating buildings and the possibility of heat production by the solar system. The values of heat production from biomass boilers and the solar system are presented in Figure 9 with a division into particular days of the heating season. The highest values of heat production from biomass boilers correspond to periods of the lowest temperatures in January and February (Fig. 9a).
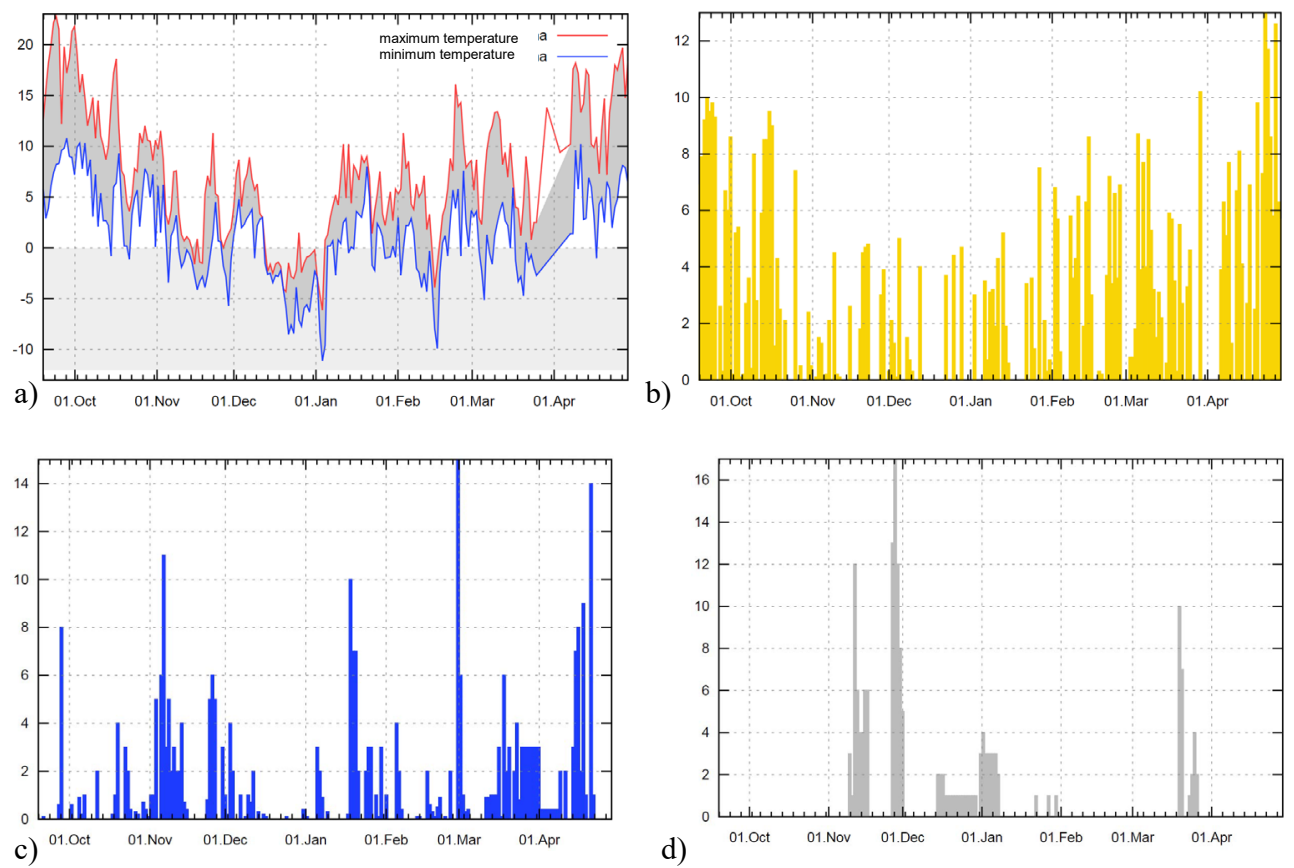

Fig. 8. Weather data for the period 01.10.2007-30.04.2008 for Czestochowa: a) maximum temperature $\left[{ }^{\circ} \mathrm{C}\right]$, minimum temperature $\left[{ }^{\circ} \mathrm{C}\right], \mathrm{b}$ ) sun hours $\left.[\mathrm{h}], \mathrm{c}\right)$ rainfall $\left.[\mathrm{mm}], \mathrm{d}\right)$ height of the snow cover $[\mathrm{cm}][2]$.

The production of heat from the solar installation is strongly associated with weather conditions (sun hours, rainfall and height of the snow cover). The heat production of the solar installation, shown in Figure $9 \mathrm{~b}$, clearly shows a decrease in the heat produced in January and February due to unfavorable weather conditions.
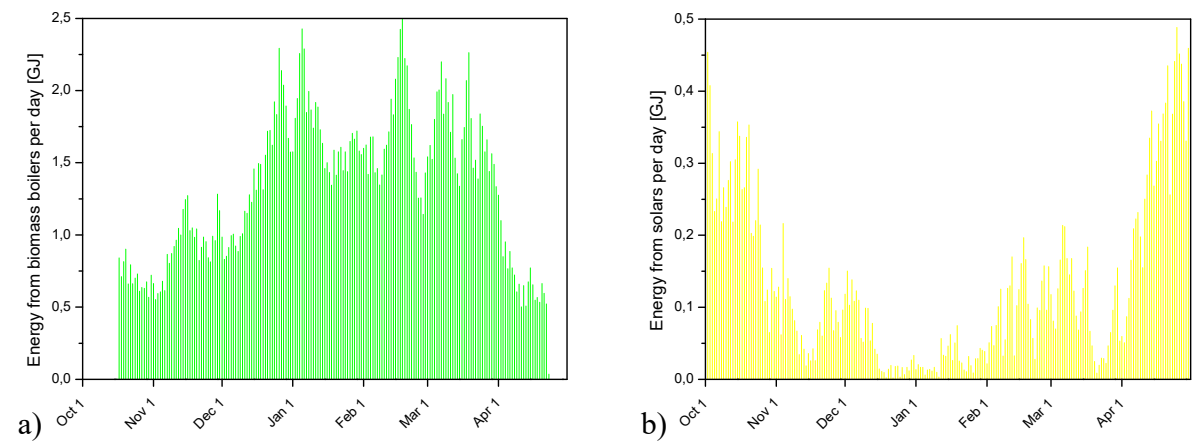

Fig. 9. Energy from: a) biomass boilers per day [GJ], b) solars per day [GJ]. 


\section{Functional problems of the installation using solar systems}

The working medium used in solar installations circulates in the closed system between the collectors and the buffer. In order to ensure the life of an installation, the working medium has to meet a series of criteria e.g.:

- resistance to crystallization,

- lack of foaming during changes in temperature and pressure in the system,

- resistance to installation stagnation temperature.

Meeting the last of these criteria by the working medium eliminates the problems resulting from overheating of the installation. Overheating of solar installations is one of the major causes of degradation of the materials used for construction of collectors [3]. This phenomenon is observed if adequate heat transport from the collector is not ensured. Consequently, the heating medium can be overheated and pressure in the installation increases [4-6]. Overheating of the installation is observed if the temperature in collectors is higher than the predicted switch-off temperature for the circulating pump. It is determined in order to protect components of installation, typically ranging from 110 to $150^{\circ} \mathrm{C}$. If the circulating pump stops operating, heat is not received and a further increase in collector temperature is observed while the heating medium starts boiling, which results in the stagnation state. Exceeding the critical temperature leads to damaging of the expansion vessel, circulating pump rotor, damaging thermal insulation of pipes and degradation of the heating medium. With prolonged overheating, glycol can also lose its properties. With a very high increase in temperature (over $200^{\circ} \mathrm{C}$ ), the mixture is divided into these components: water from glycol solution evaporates, fills in the installation and ousts glycol. In solar collectors with very low stagnation temperature, the heating medium is not damaged through stagnation since solar collector stagnation temperature is a design characteristic of the collector that reflects its performance [7]. A high stagnation temperature reflects increased access of solar radiation to the absorber and more efficient thermal insulation. Solar collector efficiency under conditions of stagnation temperature equals zero: profits from solar radiation energy are balanced by collector heat loss. The curve of solar collector efficiency is determined by two points. On the left, this is the optical collector efficiency commonly used in technical specifications (the highest efficiency at no heat loss) and, on the right side, the point on the horizontal axis, where efficiency will be zero (Fig. 10.). Stagnation temperature is defined according to the standard PN-EN 12975-2 according to two permissible methods, with possible differences in final results [8].



Fig. 10. Comparison of solar collector efficiency and stagnation temperature (ST). 
The working medium used for heat collection in solar installations is provided by dedicated mixture based on glycol. Glycol additives include [9]:

- foam inhibitors (preventing creation of gaseous phase in the installation, which can prevent from heat exchange);

- inhibitors of corrosion of copper components in the installation;

- colourants that allow for determination of the state and quality of mixture.

The most important parameters which have to characterize fuels used in solar installations include: freeze-thaw resistance, boiling point, density and viscosity, $\mathrm{pH}$. The mixtures available in the market include Tyfocor LS, Coracon Sol 5F, Therm N, OEM LT [10].

Apart from problems connected with degradation of the working medium, electrochemical corrosion occurs, resulting from the fact that two metals with different standard potentials $\left(\Delta E^{0}\right)$ show tendencies for oxidation or reduction during contact by means of electrolyte. Two metals immersed in a conducting solution create a cell, with a more active material (showing lower $\Delta E^{0}$ compared to the other metal) being dissolved. A more precious metal (with higher $\Delta E^{0}$ compared to the metal in contact) is reduced and is protected (not subjected to corrosion). A magnesium electrode is used in domestic hot water tanks in order to protect steel tanks, which, as a material with lower $\Delta E^{0}$, is subject to corrosion, thus protecting the steel tank. Since a magnesium electrode is gradually consumed, periodical inspections are necessary and the electrode should be replaced every 2 to 3 years. The corrosion rate of the magnesium electrode depends on many factors. These include e.g. water composition, water temperature, quality and state of protective coating of the domestic hot water tank.

The phenomenon typical of solar installations is cracking of heating tubes caused by prolonged exposure to low temperature (especially in the winter season). This risk occurs in heat pipe collectors, with an indirect flow, where circulation in the collector cannot be forced during a decline in temperature of the solar fluid below the critical level [11-12]. Such collectors do not have an option of a direct connection to the solar installation, whereas heat exchange occurs through heat exchanger and is related to heat recovery through condensation of the fluid evaporated in the tube. With excessively low temperatures that occur over a long period of time, the fluid in the tube cannot be evaporated. Therefore, it remains in the condensed form in its lower part and, during substantial frosts, especially at night, it can freeze and blow the tube apart. The phenomenon is difficult to be detected since the outflow of the fluid occurs only to the inside of the glass tube, which, consequently, has no effect on the operation of the solar installation. A noticeable decline in collector heat power or fogged up tubes can be observed in the situation of insolation. If more heat pipes are damaged, the installation performance is substantially reduced.

Destruction of the components of solar installations can be caused by external factors i.e. hailstorm, rapid wind, shock etc. In cheaper solutions, where boron-chromium glass, with low resistance to hailstorms is used, it can lead to damaging of the glass tubes. Pipes in more expensive collectors are made of tempered glass.

In the case of flat plate collectors, which, unlike tube collectors, are not hermetic, the phenomenon of collector fogging is observed [13]. Frequent changes in humidity inside the flat collector i.e. a low level of humidity over the day when the collector is heated and a high level of humidity during condensation at night, are responsible for the phenomenon. Fogging of the flat plate collector glasses can in many cases adopt the form which is harmful for the collector structure when:

- the collector works in a humid or misty air e.g. operation in mountain valleys near water tanks, 
- collector is positioned too flat, which disturbs the exchange of air and leads to a slower evaporation of the collector,

- the collector operates at low parameters, which leads to slower evaporation of the condensate, e.g. heating water in a swimming pool,

- the collector was improperly installed on the roof: each flat plate collector should have a minimal distance from the roof surface in order to protect it against rainwater pouring inside,

- collector ventilation holes are dirty or clogged by e.g. leaves, seeds.

\section{Conclusions}

The solution in the form of a combination of biomass boiler with solar collectors for preparation of domestic hot water in the heating off season is a perfect solution due to the opportunities of the most available renewable energy sources, also in unstable weather conditions. Heating of domestic hot water using biomass and solar energy can be used everywhere. A disadvantage of the solution is low energy density that is characterized by a relatively high surface for installation. Over 30 to 50 times more land for growing plants is needed for production of biofuel required for attaining the same energy compared to solar collectors [13]. The potential for development of this technology is very high, both in households and public utility buildings (swimming pools, schools, office buildings). At the end of 2013, around 213 installations were present in over 15 countries, of which 199 installations concerned heating. Problems with the use of combined systems of heat generation from biomass and solar energy occur in the summer season, when installations can be overheated due to insufficient heat transfer. The solution for this problem can be to build buffer tanks with a volume that allows for a safe storage of excess heat obtained from installation of solar collectors. However, the best solutions is to build solar installation in the objects where demand for heat can be predicted with high probability. Such objects include first of all hospitals, hotels where heat can be transferred continuously. In the case of other public utility facilities, one should assume heat exchange for only 5 days a week, with the installation of adequate buffer tanks allowing for storage of heat over the weekend. Due to the operation of solar systems, the less efficient are such public utility buildings as schools and universities, where, due to the summer holiday, demand for heat in June and August is nearly zero, while the solar system has the highest capacity. If installations are not properly installed in such buildings and protected from overheating, there is a high risk of their damage or failure.

From the standpoint of the life of the installation and limitation of the phenomenon of corrosion in solar installations it is important to systematically inspect solar installations in terms of quality of the installation itself, materials it was made of and the quality of a heating medium. Even a short overheating of a solar installation can lead to the damage of the expansion vessel, thermal insulation of the tubes, membrane, or the circulating pump rotor and, firstly, the heating medium. In practice, there are solar installations that work with the same glycol for a period longer than 10 years. However, the precondition is to ensure regular maintenance inspections.

The research was financed by grants No.BS/PB-404-301/11 


\section{References}

1. J. Rudniak, Z. Bis, M. Olas, Zintegrowany, inteligentny system przetwarzania energii odnawialnej, (materiały konferencyjne konferencji „Zintegrowane, inteligentne systemy wykorzystania energii odnawialnej”, 1-9, Częstochowa-Podlesice 2005)

2. www.weatheronline.pl (April 2018)

3. Www.swiatoze.pl (April 2018)

4. Y. Tian, C.Y. Zhao, A review of solar collectors and thermal energy storage in solar thermal applications, 104, 538-553 (2013)

5. S.P. Chow, G.L. Harding, R.E. Collins, Degradation of all-glass evacuated solar collector tubes, Solar Energy Materials, 12(1), 1-41 (1985)

6. I. Budihardjo, G.L. Morrison, Performance of water-in-glass evacuated tube solar water heaters, Solar Energy, 83(1), 49-56 (2009)

7. M. Thirugnanasambandam, S. Iniyan, R. Goic, A review of solar thermal technologies, Renewable and Sustainable Energy Reviews, 14(1), 312-322 (2010)

8. PN-EN ISO 9806:2014-02 - wersja angielska: Energia słoneczna - Słoneczne kolektory grzewcze - Metody badań

9. R. Tytko, Urządzenia i systemy energetyki odnawialnej, (Towarzystwo Słowaków w Polsce, Kraków 2017)

10. A. Mroziński (red.), Inżynieria instalacji solarnych, (Wydawnictwo współfinansowane ze środków funduszy norweskich oraz środków krajowych, Bydgoszcz 2016)

11. www.instalator.pl (April 2018)

12. H. Latała, Wpływ zewnętrznych warunków klimatycznych na efektywność pracy próżniowego kolektora słonecznego, (Inżynieria Rolnicza nr 1(119)/2010)

13. www.instsani.pl (April 2018) 